\title{
SINGLE-MACHINE SEQUENCING WITH PRECEDENCE CONSTRAINTS AND DEFERRAL COSTS
}

\author{
Tadashi Kurisu \\ Osaka University
}

(Received April 13, 1978; Revised August 30, 19'78)

\begin{abstract}
This paper deals with the problem of sequencing $n$ jobs on a single machine. Associated with each job is its processing time and its deferral rate. In addition, a general precedence relation exists among jobs. The problem is to find the job sequence which is consistent with the precedence relation so as to minimize the sum of the deferral cost. This problem has been considered by Sidney and he has presented a decomposition algorithm. In this paper, it is shown that Sidney's algorithm is not effective for some cases. A new algorithm is presented and it is proved that the algorithm produces an optimal sequence. An illustrative example is shown in the final section.
\end{abstract}

\section{Introduction}

We consider the problem of scheduling a set of jobs $J=\{1,2, \ldots, n\}$ to be processed on a single machine. Associated with job $i$ is its processing time $p_{i}$ and its deferral rate $w_{i}(>0)$. For a given permutation $\Pi$ of $n$ jobs, the flow time of job $i$, denoted $F_{i}(I)$, is the processing time $p_{i}$ of job $i$ plus the processing times $p_{k}$ of all jobs $k$ that are ordered before $i$ in the permutation $\Pi$. The problem is to find a permutation $\Pi$ of the jobs in $J$, such that the total cost, given by $\mathrm{TC}(\Pi)=\sum_{i=1}^{n} w_{i} F_{i}(\mathrm{I})$ is minimized. If every permutation of $n$ jobs is feasible, then the optimal sequence is determined by computing the ratio $p_{i} / w_{i}$ for each job $i$ and then ordering the jobs in the order of non-decreasing ratio. This result is due originally to Smith [6].

In this paper, we consider the above problem when some of the permutations of jobs are prohibited either by technological constraints or by externally imposed policy. The problem now is to find the feasible ordering with the lowest cost. This problem was considered by many researchers. For example, some special cases were solved by Conway, Maxwel1 and Miller [3], Horn [4], Sidney [5] and Adolphson [1]. However, the general case has not 
been solved satisfactorily as will be seen in the next section.

\section{Description of Problem}

Consider a job-shop consisting of a single machine and a set $J=\{1,2$, $\ldots, n\}$ of $n$ jobs to be processed on the machine. Associated with job $i$ is its processing time $p_{i}$ and its deferral rate $w_{i}(>0)$. The machine is continuously available from time 0 until all jobs have been completed.

An ordered set of jobs $(r, s, \ldots, t)$ is said to be a string if and only if the jobs in the set must be processed according to the fixed order $r, s$, $\ldots, t$ without interruption between jobs. We assume that the original $n$ jobs have been grouped into $m$ disjoint strings $I_{1}, I_{2}, \ldots, I_{m}$ and we set $X=$ $\left\{I_{1}, I_{2}, \ldots, I_{m}\right\}$. We further assume that a partial ordering between strings is given by a binary relationship called precedence. If for some reason the processing of the string $\mathrm{I}_{i}$ must be completed before the processing of the string $I_{j}$ begins, then $I_{i}$ is said to precede $I_{j}$ and is written $I_{i}>I_{j}$. If $\mathrm{I}_{i}>\mathrm{I}_{j}$ and there is no string, $\mathrm{I}_{k}$, such that $\mathrm{I}_{i}>\mathrm{I}_{k}>\mathrm{I}_{j}$, then $\mathrm{I}_{i}$ is said to directly precede $\mathrm{I}_{j}$ and is written $\mathrm{I}_{i} \gg \mathrm{I}_{j}$. These precedence relationships are represented by a directed acyclic graph $G$ in which an arrow from node $I_{i}$ to node $I_{j}$ indicates that $I_{i}$ must precede $I_{j}$ in any feasible ordering. The problem we consider is to obtain a sequence minimizing the total cost subject to given precedence constraints represented by a precedence graph $G=$ $(X, U)$, where $U$ denotes the set of arrows. This general problem was considered by Sidney [5]. (Note: in his model, each string consists of a job.) He presented the following decomposition algorithm and it is proved that a permutation is optimal if and only if it can be generated by the algorithm: Decomposition algorithm

Step 1. Consider all initial sets among the unscheduled jobs and find the largest initial set $s *$ that minimizes the quantity $\sum_{i \in S} p_{i} / \sum_{i \in S} w_{i}$

Step 2. Find an optimal order for the jobs in $S^{*}$ and add the jobs in $S^{*}$ to the sequence.

Step 3. Remove the jobs in $s^{*}$ from consideration and return to Step 1 until all jobs are scheduled.

Sidney does not give any method for finding an optimal order for the jobs in $S^{*}$. As Baker [2] pointed out, the general problem is not truly solved until efficient mechanisms have been designed for the following two steps:

1. Identification of $S^{*}$ (step 1 ). 
2. Sequencing of jobs in $S *$ (Step 2).

These are fairly difficult to perform efficiently in the general case as will be seen in Example 1.

Example 1. Suppose that there are nine strings with the precedence graph $G_{1}$ as indicated in Fig. 1. We assume that each string $I_{i}$ consists of a job $i$

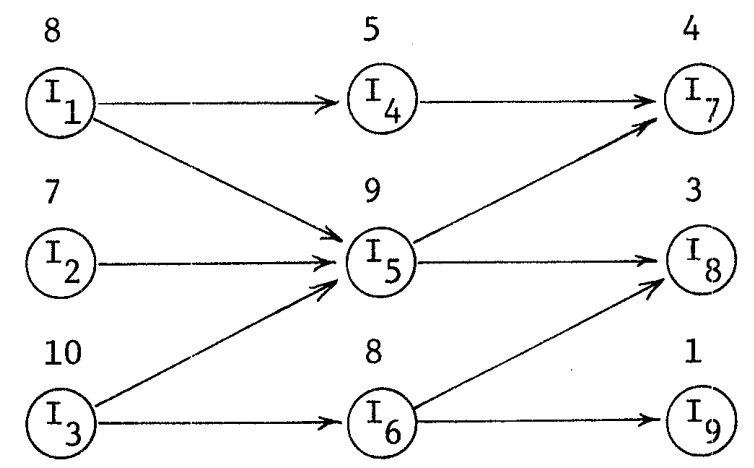

Fig. 1. Precedence Graph $G_{1}$

Table 1. Initial set $S$ and $\rho(S)=\sum_{i \in S} p_{i} / \sum_{i \varepsilon S} w_{i}$

\begin{tabular}{|c|c|c|c|}
\hline $\mathrm{s}$ & $\rho(S)$ & S & $\rho(S)$ \\
\hline$\{1\}$ & 8.0 & $\{2,3,6,9\}$ & 6.5 \\
\hline$\{2\}$ & 7.0 & $\{1,2,3,4,5\}$ & 7.8 \\
\hline$\{3\}$ & 10.0 & $\{1,2,3,4,6\}$ & 7.6 \\
\hline$\{1,2\}$ & 7.5 & $\{1,2,3,5,6\}$ & 8.4 \\
\hline$\{1,3\}$ & 9.0 & $\{1,2,3,6,9\}$ & 6.8 \\
\hline$\{1,4\}$ & 6.5 & $\{1,3,4,6,9\}$ & 6.4 \\
\hline$\{2,3\}$ & 8.5 & $\{1,2,3,4,5,6\}$ & 7.83 \\
\hline$\{3,6\}$ & 9.0 & $\{1,2,3,4,5,7\}$ & 7.17 \\
\hline$\{1,2,3\}$ & 8.33 & $\{1,2,3,4,6,9\}$ & 6.5 \\
\hline$\{1,2,4\}$ & 6.67 & $\{1,2,3,5,6,8\}$ & 7.5 \\
\hline$\{1,3,4\}$ & 7.67 & $\{1,2,3,5,6,9\}$ & 7.17 \\
\hline$\{1,3,6\}$ & 8.67 & $\{1,2,3,4,5,6,7\}$ & 7.29 \\
\hline$\{2,3,6\}$ & 8.33 & $\{1,2,3,4,5,6,8\}$ & 7.14 \\
\hline$\{3,6,9\}$ & 6.33 & $\{1,2,3,4,5,6,9\}$ & 6.86 \\
\hline$\{1,2,3,4\}$ & 7.5 & $\{1,2,3,5,6,8,9\}$ & 6.57 \\
\hline$\{1,2,3,5\}$ & 8.5 & $\{1,2,3,4,5,6,7,8\}$ & 6.75 \\
\hline$\{1,2,3,6\}$ & 8.25 & $\{1,2,3,4,5,6,7,9\}$ & 6.5 \\
\hline$\{1,3,4,6\}$ & 7.75 & $\{1,2,3,4,5,6,8,9\}$ & 6.38 \\
\hline$\{1,3,6,9\}$ & 6.75 & $\{1,2,3,4,5,6,7,8,9\}$ & 6.11 \\
\hline
\end{tabular}


and that deferral rate of each job is equal to one. Processing time of job $i$ is shown, in Fig. 1, above the description of the string $I_{i}=\{i\}$.

Step 1. There are 38 initial sets as shown in Table 1 . From the table, we read that $S *=\{1,2,3,4,5,6,7,8,9\}$ minimizes $\sum_{i \varepsilon S} p_{i} / \sum_{i \varepsilon S} w_{i}$

Step 2. Finding an optimal sequence for the jobs in $S^{*}$ is just the original problem. Thus, the algorithm presented by sidney is not applicable to this problem.

Furthermore, Adolphson [1] considered the same problem and gave an algorithm. His algorithm terminates when either the optimal sequence is found or when none of the transformations can be applied (in which case, the optimal sequence can not be found). An example of the latter case is shown in his paper.

3. Theorems and a New Algorithm

In this section, we give several theorems and a new algorithm to obtain a sequence minimizing the total cost subject to precedence constraints represented by a precedence graph $G=(X, U)$.

We set

$$
\begin{aligned}
& p\left(\mathrm{I}_{i}\right)=\sum_{j \in I_{i}} p_{j}, \\
& w\left(\mathrm{I}_{i}\right)=\sum_{j \in \mathrm{I}_{i}} w_{j}
\end{aligned}
$$

and

$$
\rho\left(I_{i}\right)=p\left(I_{i}\right) / w\left(I_{i}\right) .
$$

Theorem 1. (Sidney [5], Lemma 1) Let II and $\Pi^{\prime}$ be permutations of strings in $\mathrm{X}-\left\{\mathrm{I}_{i}\right\}$. If

$$
\mathrm{TC}(\Pi) \leqq \mathrm{TC}\left(\Pi^{\prime}\right) \text {, }
$$

then

and

$$
\operatorname{TC}\left\{\left(I_{i}, \Pi\right)\right\} \leqq \operatorname{TC}\left\{\left(I_{i}, \Pi^{\prime}\right)\right\}
$$

$$
\operatorname{TC}\left\{\left(I, I_{i}\right)\right\} \leqq \operatorname{TC}\left\{\left(\Pi^{\prime}, I_{i}\right)\right\} .
$$

Lemma 1. (Sidney [5], Lemma 2) Let $\pi=\left(I_{1}, I_{2}, I_{3}, I_{4}\right)$ and $\Pi \cdot=\left(I_{1}\right.$, $I_{3}, I_{2}, I_{4}$ ) be feasible sequences, where $I_{1}$ or $I_{4}$ or both may be empty. Then $\mathrm{TC}(\mathrm{II}) \leqq \mathrm{TC}\left(\mathrm{I}^{\prime}\right)$ if and only if $\rho\left(\mathrm{I}_{2}\right) \leqq \rho\left(\mathrm{I}_{3}\right)$.

For a precedence graph $G=(X, U)$, we set

$$
\mathrm{P}\left(\mathrm{I}_{i}, \mathrm{G}\right)=\left\{\mathrm{I}_{j} \in \mathrm{X} \mid \mathrm{I}_{j} \gg \mathrm{I}_{i}\right\},
$$




$$
\begin{aligned}
& \mathrm{Q}\left(\mathrm{I}_{i}, \mathrm{G}\right)=\left\{\mathrm{I}_{j} \varepsilon \mathrm{X} \mid \mathrm{I}_{i} \gg \mathrm{I}_{j}\right\} \\
& \mathrm{P}(\mathrm{G})=\left\{\mathrm{I}_{i} \varepsilon \mathrm{X} \mid \mathrm{P}\left(\mathrm{I}_{i}, \mathrm{G}\right)=\phi\right\}
\end{aligned}
$$

and

$$
Q(G)=\left\{I_{i} \varepsilon X \mid Q\left(I_{i}, G\right)=\phi\right\} .
$$

Theorem 2. If

$$
\rho\left(I_{i}\right) \leqq \rho\left(I_{j}\right) \quad \text { for all } I_{j} \text { in } X,
$$

then there exists an optimal sequence - minimizing the total cost subject to precedence constraints represented by a precedence graph $G=(X, U)-$ in which a string in $P\left(I_{i}, G\right)$ is sequenced directly before $I_{i}$.

Proof. Let II' be an optimal sequence and let $I_{j}$ be the string ordered last among the strings in $\mathrm{P}\left(\mathrm{I}_{i}, \mathrm{G}\right)$ under the sequence $\Pi^{\prime}$, i.e.,

$$
\Pi^{\prime}=\left(\mathrm{V}_{1}, \mathrm{I}_{j}, \mathrm{~V}_{2}, \mathrm{I}_{i}, \mathrm{~V}_{3}\right) \text {, }
$$

where $v_{1}, v_{2}$ and $v_{3}$ represent the portions of the sequence occupied by the strings other than $\mathrm{I}_{i}$ and $\mathrm{I}_{j}$, and $\mathrm{V}_{1}$ contains all the strings which belong to $\mathrm{P}\left(\mathrm{I}_{i}, \mathrm{G}\right)-\left\{\mathrm{I}_{j}\right\}$. If $\mathrm{V}_{2}$ is empty, nothing remains to prove. If $\mathrm{V}_{2}$ is not empty, we modify this sequence $\Pi^{\prime}$ to obtain:

$$
I=\left(\mathrm{V}_{1}, \mathrm{I}_{j}, \mathrm{I}_{i}, \mathrm{~V}_{2}, \mathrm{~V}_{3}\right) \text {. }
$$

The given precedence constraints are observed by $I I$, since they are observed by $I^{\prime}$ and the strings in $V_{2}$ may be ordered after the string $I_{i}$. By assumption,

$$
\rho\left(I_{i}\right) \leqq \rho\left(I_{k}\right)=\frac{p\left(I_{k}\right)}{w\left(I_{k}\right)} \quad \text { for all } I_{k} \text { in } V_{2} \text {, }
$$

and thus,

$$
\rho\left(I_{i}\right) \leqq \frac{\sum_{k} \varepsilon V_{2} p\left(I_{k}\right)}{\sum_{I_{k} \in V_{2}} w\left(I_{k}\right)}=\rho\left(V_{2}\right) .
$$

Therefore, from Lemma 1 , we have $\mathrm{TC}(\mathbb{I}) \leqq \mathrm{TC}\left(\Pi^{\prime}\right)$. Thus, $\Pi$ is also an optimal sequence. This completes our proof.

By an entirely analogous argument, we obtain the following theorem:

Theorem 3. If

$$
\rho\left(I_{i}\right) \geqq \rho\left(I_{j}\right) \quad \text { for all } I_{j} \text { in } \mathrm{X} \text {, }
$$

Then there exists an optimal sequence - minimizing the total cost subject to precedence constraints represented by a precedence graph $G=(X, U)-$ in which a string in $Q\left(I_{i}, G\right)$ is sequenced directly after $I_{i}$.

Let $I_{i}=(r, s, \ldots, t)$ and $I_{j}=(u, v, \ldots, w)$ be strings. We denote a new string $(r, s, \ldots, t, u, v, \ldots, w)$ by $\left(I_{i}, I_{j}\right)$. Suppose it is decided 
that the jobs in $I_{j}$ are ordered directly after the jobs in $I_{i}$ where $I_{j} \varepsilon$ $Q\left(I_{i}, G\right)-$ or equivalently $I_{i} \in P\left(I_{j}, G\right)-$, then $I_{i}$ and $I_{j}$ are regarded as to constitute a string $\left(I_{i}, I_{j}\right)$. In this case, for satisfying the precedence relations represented by $G$, the strings which must be processed before the strings $I_{i}$ and/or $I_{j}$ must be processed before the string $\left(I_{i}, I_{j}\right)$, and the strings which must be processed after the strings $\mathrm{I}_{i}$ and/or $\mathrm{I}_{j}$ must be processed after the string $\left(I_{i}, I_{j}\right)$. Hence, the precedence graph $G=(X, U)$ must be altered by the following procedure:

(i) Change $\mathrm{X}$ into $\mathrm{X}-\left\{\mathrm{I}_{i}\right\}-\left\{\mathrm{I}_{j}\right\}+\left\{\left(\mathrm{I}_{i}, \mathrm{I}_{j}\right)\right\}$ and remove the arrow from $\mathrm{I}_{i}$ to $I_{j}$.

(ii) Change each arrow from $I_{k}$ to $I_{i}$ into an arrow from $I_{k}$ to $\left(I_{i}, I_{j}\right)$.

(iii) Change each arrow from $I_{j}$ to $I_{k}$ into an arrow from $\left(I_{i}, I_{j}\right)$ to $I_{k}$.

(iv) Change each arrow from $I_{k}$ to $I_{j}$ with $I_{k} \neq I_{i}$ into an arrow from $I_{k}$ to $\left(I_{i}, I_{j}\right)$.

(v) Change each arrow from $I_{i}$ to $I_{k}$ with $I_{k} \neq I_{j}$ into an arrow from $\left(I_{i}, I_{j}\right)$ to $I_{k}$.

(vi) If there are arrows which are implied by a set of arrows after (ii) to (v), remove the implied precedence arrows.

We denote the resultant graph by $\mathrm{G} \mid\left\{\mathrm{I}_{i}, \mathrm{I}_{j}\right\}$.

We now generate a set $C(G)$ from a precedence graph $G=(X, U)$ by the following algorithm. In Theorem 4, we prove that an optimal sequence which minimizes the total cost subject to precedence constraints represented by a precedence graph $\mathrm{G}-$ exists in $\mathrm{C}(\mathrm{G})$.

Algorithm.

Step 0. Set

$$
\begin{array}{ll}
\mathrm{B}=\mathrm{A}=\phi, & \\
I_{i}^{*}=I_{i}, & \text { for } i=1,2, \ldots, m, \\
p\left(I_{i}^{*}\right)=\sum_{j \varepsilon I} p_{j}^{*}, & \text { for } i=1,2, \ldots, m, \\
w\left(I_{i}^{*}\right)=\sum_{j \varepsilon I_{2}^{*}} w_{j}, & \text { for } i=1,2, \ldots, m, \\
\rho\left(I_{i}^{*}\right)=p\left(I_{i}^{*}\right) / w\left(I_{i}^{*}\right), & \text { for } i=1,2, \ldots, m, \\
X^{*}=\left\{I_{1}^{*}, I_{2}^{*}, \ldots, I_{m}^{*}\right\} &
\end{array}
$$

and

$G^{*}=\left(X^{*}, U^{*}\right)$, where $U^{*}$ denotes the set of arrows between $I_{i}^{*}$ and $I_{J}^{*}$ corresponding to the arrows between $I_{i}$ and $I_{j}$ in $U$.

Go to Step 1.

Step 1. If there is no arrow in the current precedence graph $\mathrm{G}^{*}$, then obtain 
a sequence $\Pi^{\prime}$ by ordering the strings in $X^{*}$ according to the nondecreasing $\rho\left(I_{i}^{*}\right)$ and let $\Pi=\left(B, \Pi^{\prime}, A\right)$ be an element in $C(G)$ and delete $G^{*}$. If another $G^{*}$ remains yet, repeat Step $I$ for the $G^{*}$, otherwise stop the algorithm. If the current precedence graph $G^{*}$ has some arrows, go to Step 2.

Step 2. If there is only one string $I_{i}^{*}$ in $P\left(G^{*}\right)$ or there is a string $I_{i}^{*}$ in $P\left(G^{*}\right)$ such that

$$
\rho\left(I_{i}^{*}\right) \leqq \rho\left(I_{j}^{*}\right) \quad \text { for all } I_{j}^{*} \text { in } X^{*},
$$

then set $B=\left(B, I_{i}^{*}\right)$. Moreover, remove, from $G^{*}$, the string $I_{i}^{*}$ and the arrows starting from $I_{i}^{*}$ and let the resultant graph $\mathrm{G}^{*}=\left(\mathrm{X}^{*}, \mathrm{U}^{*}\right)$. Return to Step 1. If there are no such strings in $P\left(G^{*}\right)$, then go to. Step 3 .

Step 3. If there is only one string $\mathrm{I}_{i}^{*}$ in $Q\left(G^{*}\right)$ or there is a string $\mathrm{I}_{i}^{*}$ in $Q\left(G^{*}\right)$ such that

$$
\rho\left(I_{i}^{*}\right) \geqq \rho\left(I_{j}^{*}\right) \quad \text { for all } I_{j}^{*} \text { in } X^{*},
$$

then set $A=\left(I_{i}^{*}, A\right)$. Moreover, remove, from $G^{*}$, the string $I_{i}^{*}$ and the arrows terminating at $I_{i}^{*}$ and let the resultant graph $G^{*}=$ $\left(\mathrm{X}^{*}, \mathrm{U}^{*}\right)$. Return to Step 1 . If there are no such strings in $\left.\mathrm{Q}^{*} \mathrm{G}^{*}\right)$, then go to Step 4.

Step 4. Find the strings $I_{i}^{*}$ and $I_{j}^{*}$ in $X^{*}$ such that

$$
\rho\left(I_{i}^{*}\right) \leqq \rho\left(I_{k}^{*}\right) \leqq \rho\left(I_{j}^{*}\right) \text { for all } I_{k}^{*} \text { in } X^{*} \text {. }
$$

If $\left|P\left(I_{i}^{*}, G^{*}\right)\right| \leqq\left|Q\left(I_{j}^{*}, G^{*}\right)\right|^{\dagger}$, then go to Step 5 . Otherwise, go to Step 6.

Step 5. Fix a node $I_{k}^{*}$ in $P\left(I_{i}^{*}, G^{*}\right)$ and make up a new node $\left(I_{k}^{*}, I_{i}^{*}\right)$. Moreover, set

$$
\begin{aligned}
& G_{k}=G^{*} \mid\left\{I_{k}^{*}, I_{2}^{*}\right\}, \\
& p\left\{\left(I_{k}^{*}, I_{i}^{*}\right)\right\}=p\left(I_{k}^{*}\right)+p\left(I_{i}^{*}\right), \\
& w\left\{\left(I_{k}^{*}, I_{i}^{*}\right)\right\}=w\left(I_{k}^{*}\right)+w\left(I_{2}^{*}\right) \\
& \rho\left\{\left(I_{k}^{*}, I_{i}^{*}\right)\right\}=p\left\{\left(I_{k}^{*}, I_{i}^{*}\right)\right\} / \omega\left\{\left(I_{k}^{*}, I_{i}^{*}\right)\right\} .
\end{aligned}
$$

For each $I_{k}^{*}$ in $P\left(I_{2}^{*}, G^{*}\right)$, set $G^{*}=G_{k}$ and return to Step 1 .

Step 6. Fix a node $I_{k}^{*}$ in $Q\left(I_{j}^{*}, G^{*}\right)$ and make up a new node $\left(I_{j}^{*}, I_{k}^{*}\right)$. Moreover, set

$$
\begin{aligned}
& \quad \mathrm{G}_{k}=\mathrm{G}^{*} \mid\left\{I_{j}^{*}, I_{k}^{*}\right\}, \\
& \quad p\left\{\left(I_{j}^{*}, I_{k}^{*}\right)\right\}=p\left(I_{j}^{*}\right)+p\left(I_{k}^{*}\right), \\
& w\left\{\left(I_{j}^{*}, I_{k}^{*}\right)\right\}=w\left(I_{j}^{*}\right)+w\left(I_{k}^{*}\right) \\
& \text { and }
\end{aligned}
$$

$+|s|$ denotes the cardinality of the set $S$. 


$$
\begin{aligned}
& \rho\left\{\left(I_{j}^{*}, I_{k}^{*}\right)\right\}=p\left\{\left(I_{j}^{*}, I_{k}^{*}\right)\right\} / w\left\{\left(I_{j}^{*}, I_{k}^{*}\right)\right\} . \\
& \text { for each } I_{k}^{*} \text { in } Q\left(I_{j}^{*}, G^{*}\right) \text {, set } G^{*}=G_{k} \text { and return to Step } 1 .
\end{aligned}
$$

Theorem 4. For the problem to minimize the total cost subject to precedence constraints represented by a precedence graph $G=(X, U)$, there exists an optimal sequence in the set $C(G)$.

Proof. Step 1 in Algorithm is justified since there is an optimal sequence in $C(G)$ from the results of Theorem 1 and Lemma 1 . In Step 2, from Theorems 1 and 2, we can get an optimal sequence by removing the string $I_{2}$ and the arrows starting from $I_{i}^{*}$. Similarly, Step 3 is justified from Theorems 1 and 3. In Step 5, each of the $I_{\hat{k}}^{*}$ in $P\left(I_{i}^{*}, G^{*}\right)$ is considered, and thus, we can get an optimal sequence by means of Theorem 2. Similarly, Step 6 is justified from Theorem 3 .

It follows, from Theorem 4, that we can get an optimal sequence by calculating the total cost for each sequence in $C(G)$.

Remarks .

1. If there are two or more $I_{i}^{*}$ 's and/or I*j's satisfying the condition in Step 4, then any one among them may be selected. If another string is selected in Step 4, then we may get another set $C(G)$. However, every $C(G)$ contains an optimal sequence, and thus, it is sufficient to obtain one set $C(G)$ generated by the algorithm.

2. If the original precedence graph $G$ is a collection of rooted trees, then $\mathrm{P}\left(\mathrm{I}_{i}^{*}, \mathrm{G}^{*}\right)$ contains at most one node, and hence, we get $\mathrm{C}(\mathrm{G})$ with one element. Thus, we can obtain an optimal sequence directly. In this case, our algorithm looks easier than the algorithm presented by Horn [4].

\section{An Example}

In this section, we illustrate the algorithm given in the previous section by solving Example 1 .

Step 0 . We set

$$
\begin{array}{ll}
I \underset{i}{i}=I_{i}=\{i\}, & \text { for } i=1,2, \ldots, 9, \\
p\left(I_{i}\right)=p_{i}, & \text { for } i=1,2, \ldots, 9, \\
w\left(I_{i}\right)=w_{i}, & \text { for } i=1,2, \ldots, 9, \\
\rho\left(I_{i}\right)=p\left(I_{i}\right) / w\left(I_{i}\right) & \text { for } i=1,2, \ldots, 9 \\
\text { and } & \\
\rho\left(I_{i}^{*}\right)=\rho\left(I_{i}\right) & \text { for } i=1,2, \ldots, 9 .
\end{array}
$$

Step 4. Since 


$$
\rho\left(I_{9}\right) \leqq \rho\left(I_{k}^{*}\right) \leqq \rho\left(I_{3}\right) \quad \text { for all } I_{k}^{*} \text { in } G_{1}
$$

and

$$
\left|P\left(I_{9}, G_{1}\right)\right|<\left|Q\left(I_{3}, G_{1}\right)\right|
$$

we go to Step 5 .

Step 5. Since $P\left(I_{9}, G_{1}\right)=\left\{I_{6}\right\}$, it is sufficient to make up only one new string $\left(I_{6}, I_{9}\right)$, and thus, we get a precedence graph $G_{2}=G_{1} \mid\left\{I_{6}, I_{9}\right\}$ as shown in Fig. 2. (Note: in Figs. 2 to $12, \rho\left(I_{i}^{*}\right)$ is shown above the description of the string $\mathrm{I}_{i}^{*_{\bullet}}$ )

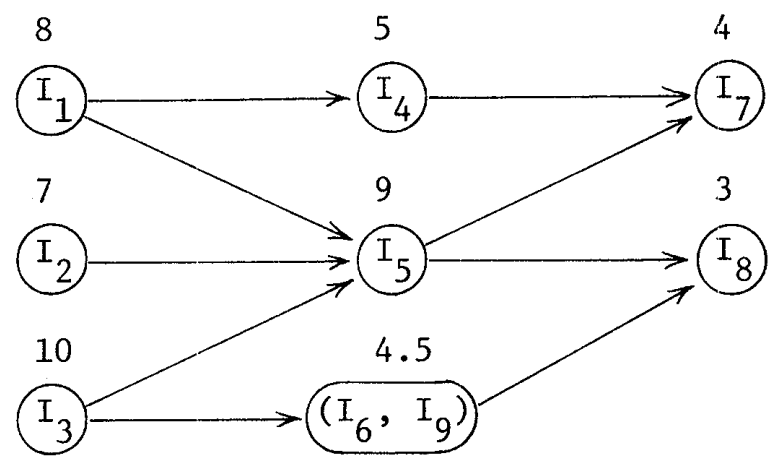

Fig. 2. Precedence Graph $\mathrm{G}_{2}$

Step 4. Since

$$
\rho\left(I_{8}\right) \leqq \rho\left(I_{k}^{*}\right) \leqq \rho\left(I_{3}\right)
$$

for all $I_{k}^{*}$ in the current precedence graph $G_{2}$ and

$$
\left|P\left(I_{8}, G_{2}\right)\right|=\left|Q\left(I_{3}, G_{2}\right)\right| \text {, }
$$

we go to Step 5 .

Step 5. Since $P\left(I_{8}, G_{2}\right)=\left\{I_{5},\left(I_{6}, I_{9}\right)\right\}$, we make up two precedence graphs $G_{3}=G_{2} \mid\left\{I_{5}, I_{8}\right\}$ and $G_{4}=G_{2} \mid\left\{\left(I_{6}, I_{9}\right), I_{8}\right\}$ as indicated in Figs. 3 and 4 , respectively.

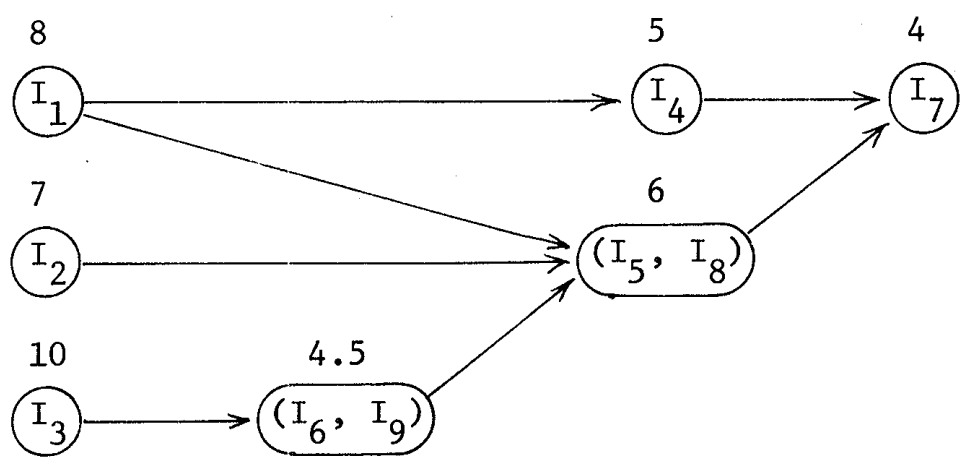

Fig. 3. Precedence Graph $G_{3}=G_{2} \mid\left\{I_{5}, I_{8}\right\}$ 


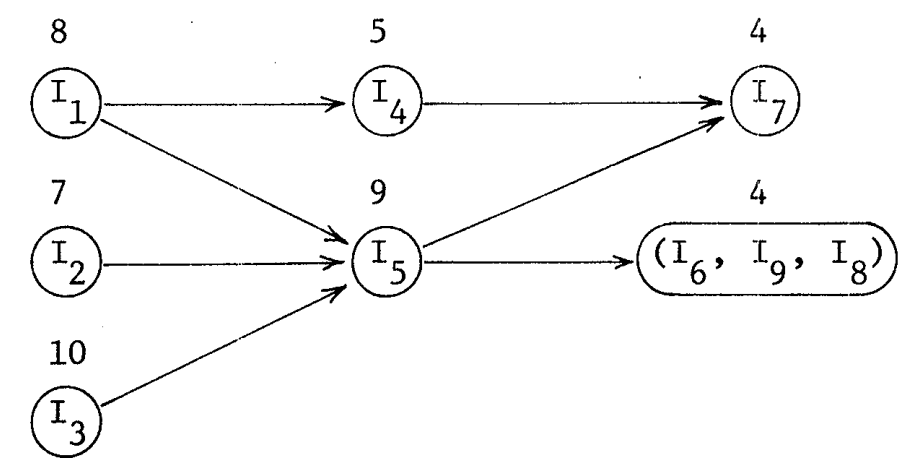

Fig. 4. Precedence Graph $G_{4}=G_{2} \mid\left\{\left(I_{6}, I_{9}\right), I_{8}\right\}$

First, starting from $G_{3}$, we get sequences belonging to $C\left(G_{1}\right)$.

Step 3. Since $Q\left(G_{3}\right)=\left\{I_{7}\right\}$, we set $A=\left(I_{7}\right)$ and get a precedence graph $G_{5}$ as shown in Fig. 5 .

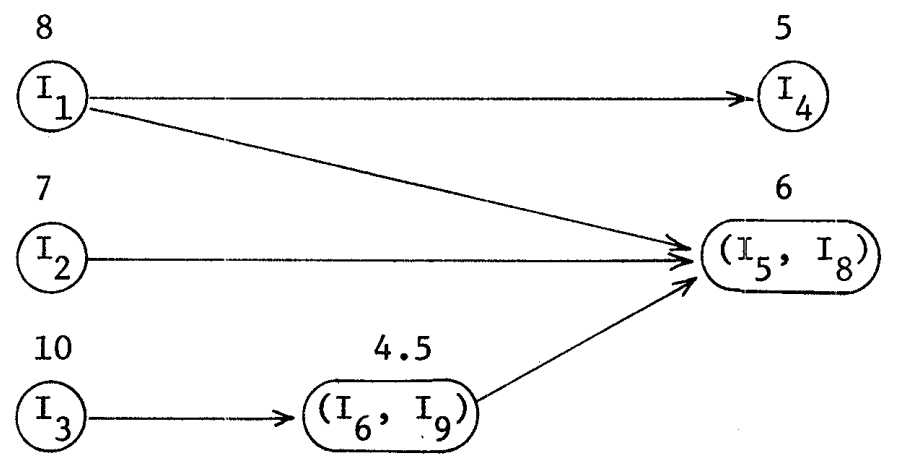

Fig. 5. Precedence Graph $G_{5}$

Step 4. Since

$$
\rho\left\{\left(I_{6}, I_{9}\right)\right\} \leqq \rho\left(I_{k}^{*}\right) \leqq \rho\left(I_{3}\right)
$$

for all $I_{k}^{*}$ in the current precedence graph $G_{5}$ and

$$
\left|Q\left(I_{3}, G_{5}\right)\right|=\left|P\left\{\left(I_{6}, I_{9}\right), G_{5}\right\}\right| \text {, }
$$

we go to Step 5 .

Step 5. Constituting a new string $\left(I_{3}, I_{6}, I_{9}\right)$, we get a precedence graph $G_{6}$ $=G_{5} \mid\left\{I_{3},\left(I_{6}, I_{9}\right)\right\}$ as indicated in Fig. 6 .

Step 4. We have

$$
\rho\left(I_{4}\right) \leqq \rho\left(I_{k}^{*}\right) \leqq \rho\left(I_{1}\right)
$$

for all $I_{k}$ in the current precedence graph $G_{6}$ and

$$
\left|P\left(I_{4}, G_{6}\right)\right|<\left|Q\left(I_{1}, G_{6}\right)\right| \text {, }
$$

and so we again go to step 5 .

Step 5. Since $P\left(I_{4}, G_{6}\right)=\left\{I_{1}\right\}$, we make up a new string $\left(I_{1}, I_{4}\right)$ and get a precedence graph $G_{7}$ as shown in Fig. 7 . 


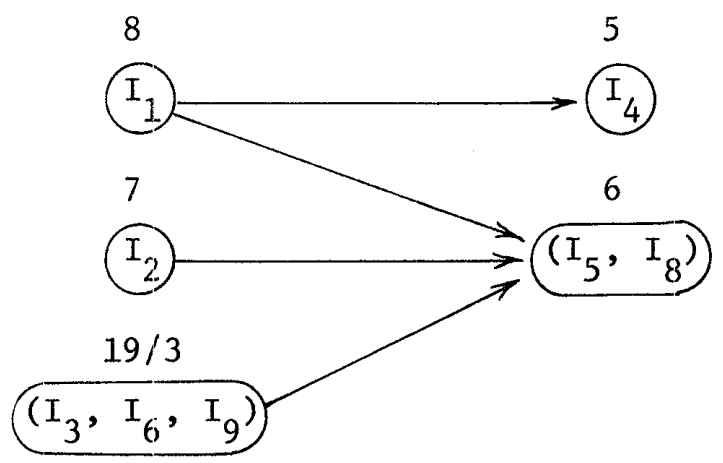

Fig. 6. Precedence Graph $G_{6}=G_{5} \mid\left\{I_{3},\left(I_{6}, I_{9}\right)\right\}$

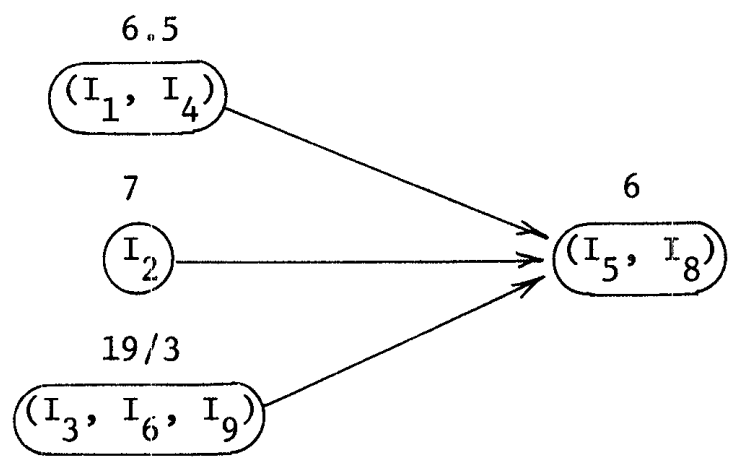

Fig. 7. Precedence Graph $G_{7}$

Step 3. Since $Q\left(G_{7}\right)=\left\{\left(I_{5}, I_{8}\right)\right\}$, we set $A=\left(I_{5}, I_{8}, I_{7}\right)$ and get a precedence graph $G_{8}$ as illustrated in Fig. 8 .

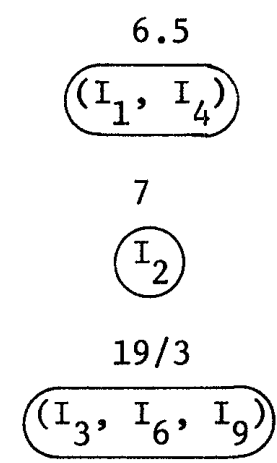

Fig. 8. Precedence Graph $G_{8}$

Step 1. It is easily seen that $\left(I_{3}, I_{6}, I_{9}, I_{1}, I_{4}, I_{2}\right)$ is an optimal sequence for the precedence graph $G_{8}$, and thus, $\Pi_{1}=(3,6,9,1,4$, $2,5,8,7)$ is an element in $C\left(G_{1}\right)$.

Next, starting from $G_{4}$, we get sequences which belong to $C\left(G_{1}\right)$. 
Step 4. Since

$$
\rho\left\{\left(I_{6}, I_{9}, I_{8}\right)\right\} \leqq \rho\left(I_{k}^{*}\right) \leqq \rho\left(I_{3}\right)
$$

for all $I_{k}^{*}$ in the current precedence graph $G_{4}$ and

$$
\left|P\left\{\left(I_{6}, I_{9}, I_{8}\right), G_{4}\right\}\right|=\left|Q\left(I_{3}, G_{4}\right)\right| \text {, }
$$

we go to Step 5 .

Step 5. We constitute a new string $\left(I_{5}, I_{6}, I_{9}, I_{8}\right)$ and get a precedence graph $G_{9}$ as indicated in Fig. 9.

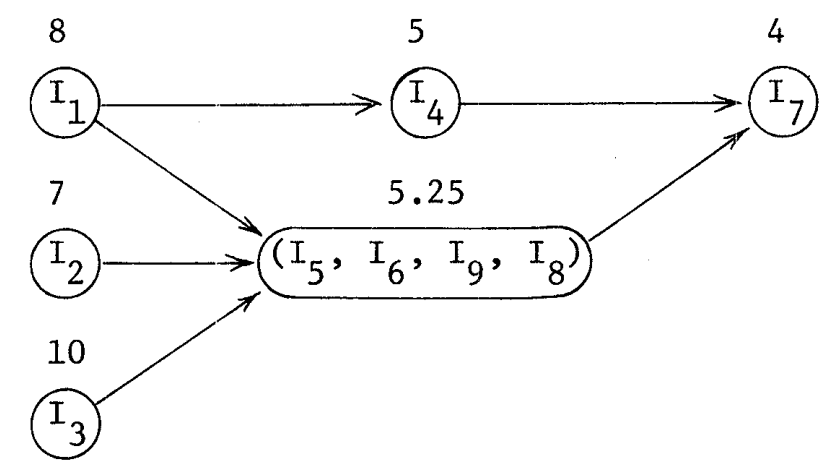

Fig. 9. Precedence Graph $G_{9}$

Step 3. As $Q\left(G_{9}\right)=\left\{I_{7}\right\}$, we set $A=\left(I_{7}\right)$ and get a precedence graph $G_{10}$ as indicated in Fig. 10.

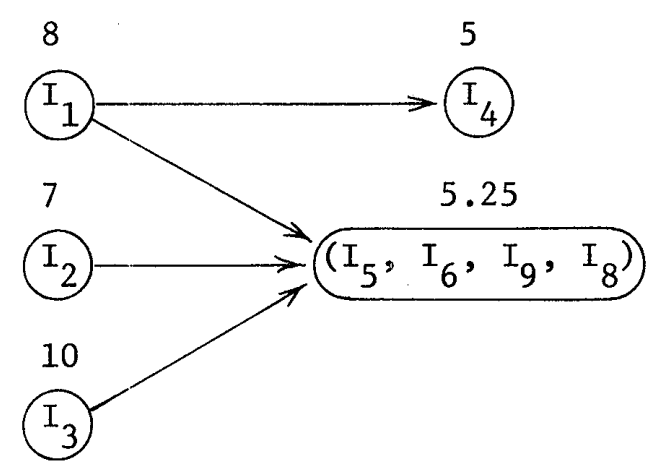

Fig. 10. Precedence Graph $G_{10}$

Step 4. Since

$$
\begin{aligned}
& \quad \rho\left(I_{4}\right) \leqq \rho\left(I_{k}^{*}\right) \leqq \rho\left(I_{3}\right) \quad \text { for al1 } I_{k}^{*} \text { in } G_{10} \\
& \text { and } \\
& \qquad\left|P\left(I_{4}, G_{10}\right)\right|=\left|Q\left(I_{3}, G_{10}\right)\right| \text {, } \\
& \text { we go to Step } 5 \text {. }
\end{aligned}
$$

Step 5. Making up a new string $\left(I_{1}, I_{4}\right)$, we get a precedence graph $G_{11}$ as shown in Fig. 11. 


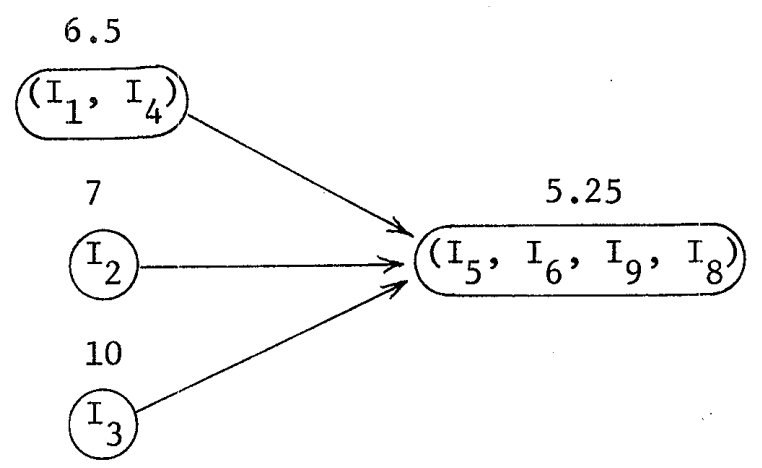

Fig. 11. Precedence Graph $G_{11}$

Step 3. Since there is only one string $\left(I_{5}, I_{6}, I_{9}, I_{8}\right)$ in $Q\left(G_{11}\right)$, we set $A=\left(I_{5}, I_{6}, I_{9}, I_{8}, I_{7}\right)$, and get a precedence graph $G_{12}$ as shown in Fig. 12 .

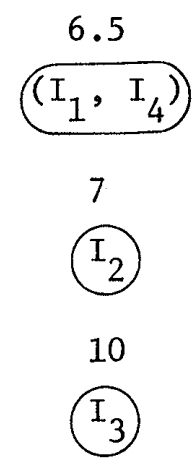

Fig. 12. Precedence Graph $G_{12}$

Step 1. Apparently, $\left(I_{1}, I_{4}, I_{2}, I_{3}\right)$ is an optimal sequence for $G_{12}$, and so, $\Pi_{2}=(1,4,2,3,5,6,9,8,7)$ is an element in $C\left(G_{1}\right)$.

Thus, we have $C\left(G_{1}\right)=\left\{\Pi_{1}, \pi_{2}\right\}$. It is easily calculated that $\operatorname{TC}\left(\pi_{1}\right)=299$ and $\mathrm{TC}\left(\Pi_{2}\right)=311$, and hence, $\Pi_{1}$ i.s an optimal sequence.

\section{Acknowledgements}

The author wishes to thank Professor M. Sakaguchi of Osaka University for his useful suggestions and valuable discussions. He also wishes to acknowledge the referees for their comments, which have greatly improved this paper. 


\section{References}

[1] Adolphson, D. L.: Single Machine Job Sequencing with Precedence Constraints. Siam Journal on Computing, Vo1. 6 (1977), pp. 40-54.

[2] Baker, K, R.: Introduction to sequencing and Scheduling, John Wiley, New York, 1974.

[3] Conway, R. W., Maxwe11, W. L., and Miller, L. W.: Theory of Scheduling, Addison-Wesley, Reading, Mass., 1967.

[4] Horn, W. A.: Single-Machine Job Sequencing with Treelike Precedence Ordering and Linear Delay Penalties. Siam Journal on Applied Mathematics, Vo1. 23 (1972), pp. 189-202.

[5] Sidney, J. B.: Decomposition Algorithms for Single-Machine Sequencing with Precedence Relations and Deferral Costs. Operations Research, Vo1. 23 (1975), pp. 283-298.

[6] Smith, W. E.: Various Optimizers for Single-Stage Production. Naval Research Logistics Quarterly, Vol. 3 (1956), pp. 59-66.

Tadashi KURISU:

Department of Applied Mathematics

Faculty of Engineering Science

Osaka University

Toyonaka, Osaka, Japan 


\section{処理順序に制約のある 1 台の機械の順序づけ問題}

大阪大学 栗 栖忠

一台の機械とこの機械で処理される $\mathrm{n}$ 個の仕事 $1 ， 2, \cdots, \mathrm{n}$ からなる順序づけ問題を考える。各 仕事 $\mathrm{i}$ には処理時間 $\mathrm{p}_{\mathrm{i}}(>0)$ と重み $\mathrm{w}_{\mathrm{i}}(>0)$ が対応しているものとする。又， $\mathrm{n}$ 個の仕事はいく つかのグループに分けられて括り，各クループの内部では処理順序は予め定まって括り，一旦一つの クループに含まれる最初の仕事の処理を開始するとそのグループに含まれるすべての仕事の処理をこ の定まった順序にしたがって完了するまで，他のグループに含まれる仕事の処理は開始できないあの とする。さらに，あるグループの仕事は他のグループの仕事より先に処理しなければならないという 形でクループ間の半順序が与えられて挌り，クループ処理順序はこの半順序を満足しなければなら ないあのとする。このような関係は各グループをnode とし先行関係を arrow とする 1 つのグラフ で表わすことができる。又，1つの処理順序による全費用をその処理順序による各仕事の完了時間に その仕事の重みをかけたものの和と定義する。我々の問題は, 処理順序が満たすべきクラフが与えら れた時, これを満足する範囲で全費用を最小にする処理順序を求めることである。この問題に対して は既に多くの研究者による研究があり，先行関係が特別な構造を持つ場合の考察がいろいるなされて いる。特に Sidneyは各グループが 1 つの仕事からなっている時を考察し，あるアルゴリズムを提案 しこのアルゴリズムによって最適な処理順序が得られることを示している。

本論文では S i d neyの与えたアルゴリズムは効率がよくなく，又，解を与えない場合があることを 例をもって示し，更に新しいアルゴリズムを与え，これによって最適な処理順序が一般の先行関係に 対して求まることを示した。このアルゴリズムの特色は $\mathrm{w}_{1}$ と $\mathrm{p}_{1}$ との関係により次々に新しいクル ープを作っていき，それに伴なって先行関係を表わすグラフを次々に作り変えていくことである。最 後に, このアルゴリズムによって最適解を求める例を示してある。 